\title{
O PROCESSO DE AUTORIA EM UM SOPRO DE VIDA (PULSAÇÕES), DE CLARICE LISPECTOR: UMA INSCRIÇÃO PARATÓPICA
}

\author{
THE AUTHORSHIP PROCESS IN UM SOPRO DE VIDA: PULSAÇÕES BY CLARICE \\ LISPECTOR: A PARATOPIC INSCRIPTION
}

Cirlana Rodrigues de Souza

Universidade Federal de Uberlândia

\begin{abstract}
RESUMO: Neste texto, nosso objetivo é analisar o processo de inscrição de autoria da escritora Clarice Lispector na e pela obra Um sopro de Vida (Pulsações), no campo discursivo literário brasileiro, a partir da perspectiva da Análise do Discurso Literário de Dominique Maingueneau (2008, 2009). Para isso, faremos uma contextualização dos fundamentos do programa de análise elaborado por esse autor e, na sequência, iremos operacionalizar na análise o conceito de cenografia como embreante paratópico considerando as categorias de enunciador e coenunciador, topografia e cronografia, elementos que compõem sua dêixis discursiva. Nossa hipótese é a de que essas cenografias constroem a complexa figura de autoria, de natureza paratópica, em Clarice Lispector, ao mesmo tempo em que tematizam a paratopia como aspecto comum aos discursos constituintes, como o discurso literário, sendo possível, então, supor um funcionamento metaparatópico da obra.
\end{abstract}

PALAVRAS-CHAVE: Análise do Discurso Literário; Autoria; Cenografia; Paratopia.

ABSTRACT: This text aims at analyzing Clarice Lispector and Um sopro de vida (Pulsações) [A breath of life (Pulsations)] regarding the authorship inscription process on the Brazilian literary discourse field, from the perspective of Dominique Maingueneau's literary discourse theory $(2008,2009)$. Thus, the article sets the basis of the analysis program developed by this author and then analyzes the scenography concept as a mesmerizing paratopic. It also considers the classes of annunciator and coannuncator, topography and chronograph, elements that constitute its discourse deixis. The hypothesis is that these scenographies build, in Lispector's book, a complex authorship person, with a paratopic nature, at the same time as they say the paratopy is a common topic at the constitutive discourses, such as the literary discourse, being possible to assume the book's metaparatopic function.

KEYWORDS: Literary Discourse Analysis; Authorship; Scenography; Paratopy.

\section{Introdução}

Este texto trata do processo de inscrição de autoria da escritora Clarice Lispector, no campo discursivo literário brasileiro, com base nas cenografias construídas na e pela obra Um Sopro de Vida (Pulsações).

Essa inscrição se caracterizaria, segundo nossa hipótese de trabalho, por uma condição paratópica coerente com a natureza do discurso literário como discurso 


\section{Revista do SELL}

v. $4, n^{\circ} .1$

ISSN: $1983-3873$

constituinte, porém com uma especificidade: a obra tematiza, entre outras questões, a paratopia por meio de um funcionamento metaparatópico em que as cenografias - como embreantes paratópicos - constroem essa cena de enunciação que, ao mesmo tempo, é paratópica e diz sobre a paratopia desse discurso literário. Dizendo de outro modo, como discurso literário, essa obra se debruça sobre sua própria condição constituinte e paratópica.

Iniciaremos nossa discussão apresentando a obra em questão dentro da produção literária da escritora Clarice Lispector. $\mathrm{Na}$ sequência, discorreremos sobre os fundamentos teóricos e analíticos da Análise do Discurso Literário elaborados por Domimique Maingueneau (2008, 2009). Desses fundamentos, de modo específico, os conceitos a serem elencados são os de discurso constituinte e de interlíngua, a problemática da autoria e a inscrição no campo discursivo literário, a paratopia, a cena da enunciação e as cenografias construídas na e pela obra como embreantes paratópicos da inscrição de Clarice Lispector, nesse campo.

Após as elaborações teóricas que focam a construção de um quadro hermenêutico para a análise discursiva na obra inicialmente mencionada, passaremos às construções analíticas das cenografias dispostas nessa obra buscando sua inscrição paratópica por meio de seu possível funcionamento metaparatópico.

Para finalizar este texto, faremos algumas considerações sobre o efeito possível dessa tematização acerca da paratopia nas discussões sobre a autoria em análise do discurso como uma inscrição necessariamente paradoxal no campo discursivo literário.

\section{A obra Um sopro de Vida (Pulsações), de Clarice Lispector}

De modo geral, a produção literária de Clarice Lispector tem sido objeto de estudo e interesse acadêmico no que diz respeito aos aspectos introspectivos de sua narrativa ficcional singular e, atualmente, em relação ao que se denomina de escrita feminina, uma produção literária atrelada à questão dos gêneros. Nosso trabalho, entretanto, não se propõe a nenhuma categorização dessa obra, mas a analisar o funcionamento discursivo de um de seus livros.

A obra Um sopro de vida (Pulsações) foi publicada em 1978, postumamente, como o último livro de Clarice Lispector. Sua escrita foi iniciada em 1974 e finalizada em 1977, pouco antes de sua morte. Esse livro foi organizado para publicação por Olga Borelli, trabalho que consistiu na edição dos manuscritos fragmentados deixados pela escritora. 


\section{Revista do SELL \\ v. $4, n^{\circ} .1$ \\ ISSN: $1983-3873$}

Até essa última obra, Clarice Lispector havia feito de sua trajetória na literatura brasileira um percurso notável, cuja direção havia sido dada já no ano de 1944 quando do lançamento de seu primeiro livro, Perto do coração Selvagem: escolha pela escritura em função do trabalho e experiência com a língua que abriu uma fenda no campo discursivo da literatura moderna brasileira. Sobre isso, Antônio Cândido (1943/1977), ao se pronunciar sobre o raiar de Lispector no campo literário brasileiro com esse primeiro livro, enfatiza que foi a exploração vocabular, uma verdadeira aventura de expressão por meio da língua, que a inscreveu como autora e escritora brasileira. $O$ autor esclarece que:

Com efeito, este romance [Perto do coração Selvagem] é uma tentativa impressionante para levar a nossa língua canhestra a domínios pouco explorados, forçando-a a adaptar-se a um pensamento cheio de mistério, para o qual sentimos que a ficção não é um exercício ou uma aventura afetiva, mas um instrumento real do espírito, capaz de nos fazer penetrar em alguns labirintos mais retorcidos da mente. (CÂNDIDO, 1943/1977, p.127)

Dessas palavras, nos interessa a exploração que a autora fez da Língua Portuguesa e fará sempre e que, neste texto, trataremos do ponto de vista discursivo como um funcionamento na interlíngua.

Ao rever o contexto literário da época, Moser (2009) também analisa que foi a "linguagem" de Clarice Lispector que, ao causar um estranhamento - uma vez que em nada se parecia com a linguagem romanesca dessa época -, arrebatou o público, a crítica e os escritores nacionais.

Moser (2009) nos chama a atenção para o fato de que esse primeiro livro de Clarice Lispector instaurou uma concepção de arte (e técnica) literária completamente diferente daquela feita, até então, pelos escritores contemporâneos a ela: um novo modo de escrever o texto literário que rompeu não apenas com a questão estrutural da escrita, por meio de uma linguagem não usual, introspectiva, de sintaxe estranha e adjetivos que irrompiam inesperadamente nas frases, mas também com a própria ideia de narrativa romanesca, o que, para a literatura brasileira, foi um corte cruel, uma vez que rompia com a problemática da nacionalidade, que era um dos núcleos dessa literatura. A literatura brasileira passou a assumir um topos no universo discursivo da literatura tratando de questões humanas universais e não somente questões políticas e sociais nacionais. Sobre os efeitos do primeiro livro de Lispector, Moser (2009, p.193) ressalta: 


\title{
Revista do SELL
}

v. $4, n^{\circ} .1$

ISSN: $1983-3873$

\begin{abstract}
É digno de nota o fato de só muito raramente os críticos compararem o livro a de outros escritores brasileiros. Em vez disso, mencionavam Joyce, Virgínia Wolf, Katherine Mansfied, Dostoiévski, Proust, Gide e Charles Morgan. Isso não ocorria apenas porque toda a questão do Brasil, aquele "instinto de nacionalidade" que Machado de Assis considerava o cerne da literatura brasileira, estava ausente de Perto do coração selvagem. É que sua linguagem não soava como brasileira. Lêdo Ivo, rememorando a "estranha voz" e a "dicção gutural" de Clarice, escreve: "Clarice Lispector era uma estrangeira [...] A estrangeiridade de sua prosa é uma das evidências mais contundentes de nossa história literária e, ainda, da história de nossa língua".
\end{abstract}

Tomemos o adjetivo estrangeira, em relação à prosa de Clarice Lispector, para qualificar sua escrita como não pertencente unicamente ao campo literário brasileiro, mas ao campo do discurso literário, sendo sua condição de autora e criadora de uma "língua literária estrangeira" marcada por essa singularidade de fazer literatura em outra "língua". Importante ressaltar que essa estrangeiridade refere-se ao que a autora fez com a Língua Portuguesa: um outro modo de colocar em uso os recursos discursivos e linguísticos dessa língua, estranho ao que prevalecia, porém não desconhecido.

Esse marco inicial instaurado pelo lançamento de seu primeiro livro manteve-se ao longo de todo o percurso de Clarice Lispector como escritora e foi sendo sempre intensificado. Em alguns momentos, sua relação com a língua e com a escritura parecia torná-la mais estrangeira ainda; entretanto, cada vez mais seu lugar como autora literária brasileira era ratificado, paradoxo que caracteriza a discursividade da obra de Clarice Lispector, pois é justamente o insistir em manter-se distante institucionalmente e em termos estéticos que a possibilita inscrever-se como autora. Nesse ponto, acreditamos que tão poucas vezes texto e contexto possam ser tomados como constitutivos de um discurso literário: ao gerir seus textos, no contexto da literatura brasileira, Clarice Lispector não diferencia um estar dentro e um estar fora, não diferencia a escrita de seu lugar de produção. Ao posicionar-se na (inter)língua - conceito que apresentaremos adiante (MAINGUENEAU, 2006) -, Lispector constrói o texto literário e, ao mesmo tempo, inscreve-se na literatura brasileira. Nesse sentido, ser autora, para Clarice Lispector, somente é possível ao escrever; ela só pode responder por sua escrita e se inscrever como autora no campo literário quando escreve. E é por meio da construção de uma cenografia em que o tempo é o instante de escrita, e o espaço, o percurso construído nesse instante, que esse processo se dá. 


\section{Revista do SELL \\ v. $4, n^{\circ} .1$ \\ ISSN: $1983-3873$}

Com base nisso, nosso interesse pela obra Um sopro de Vida (Pulsações) se justifica pela tematização da condição paratópica do discurso literário como um discurso constituinte: último topos do percurso literário de Clarice Lispector, por meio do qual ela afirma que o lugar e o tempo de pertencimento de um autor só podem ser mesmo na escrita de sua obra ${ }^{1}$.

\section{A Análise do Discurso Literário}

Este trabalho fundamenta-se nos pressupostos teóricos e analíticos da análise do discurso literário proposta por Dominique Maingueneau e sintetizados na obra Discurso Literário (2009).

Tomar o texto literário como discurso é considerar o texto, objeto e materialidade linguística, como discurso. A esse respeito, Mussalim (2011a, p. 1457) esclarece que a Análise do Discurso Literário:

(01) [...] não considera o texto literário como reflexo de uma época histórica, nem tampouco como reflexo das lutas entre classes sociais;

(02) não considera o texto literário como produto de uma visão de mundo, efeito, portanto, da manifestação de uma subjetividade;

(03) não considera o texto literário como entidade autônoma, fechada sobre si mesma, já que nega a possibilidade de uma gestão autotélica do texto.

Nesse sentido, a análise discursiva proposta por Dominique Maingueneau não separa texto e contexto histórico, em que o primeiro seria consequência, efeito direto do segundo; também a subjetividade presentificada no discurso literário não é da ordem de causa ou de uma representatividade; do mesmo modo, o texto literário não é uma estrutura imanente, uma vez que texto e contexto se relacionam em termos de constituição.

A proposta de Maingueneau (2009) é que se pense o discurso literário em termos de uma instituição literária, o que implica levar em conta: i) a literatura como uma prática discursiva autônoma, por ter seu próprio campo constituído; ii) de forma mais ampla,

\footnotetext{
${ }^{1}$ Interessante lembrar, já que nosso tema gira em torno da escrita, do processo de autoria no livro Um Sopro de Vida (Pulsações) como um complexo trabalho com a Língua Portuguesa, que o mesmo teve sua primeira tradução para o inglês, feita por Johnny Lorenz ( $A$ Breath of Life), indicada ao Prêmio de Melhor Livro Traduzido nos Estados Unidos, na categoria Ficção, de 2013, pelo centro de investigação literária, o Three Percent, da Universidade de Rochester, no estado norte-americano de Nova lorque, conforme ampla divulgação na imprensa nacional.
} 


\section{Revista do SELL}

v. $4, n^{\circ} .1$

ISSN: $1983-3873$

considerar, nas análises, a instituição discursiva que abrange tanto o aspecto de ação e processo de construção das práticas de linguagem, bem como a instituição como organização dessas práticas; iii) considerar, também, seus aspectos enunciativos e estruturais manifestados nos gêneros discursivos de uma determinada comunidade e que constituem a cena de enunciação para além de um mero contexto, abarcando obra e condições de produção instauradas em campos discursivos específicos. Desse modo, a instituição literária seria alçada à condição de discurso e se caracterizaria, fundamentalmente, por ser constituinte.

\subsection{O discurso literário como discurso constituinte, a inscrição de} autoria e a interlíngua

Maingueneau $(2008,2009)$ propõe que discursos como o religioso, o filosófico e o literário sejam enquadrados na categoria de discursos constituintes, cujas propriedades comuns permitiriam construir um projeto de análise. Para o autor, os discursos constituintes não reconhecem outra autoridade além de sua própria autoridade fundadora: fundam um campo discursivo e uma comunidade discursiva que alimenta o archeion de uma sociedade. Conforme Maingueneau (2009, p. 60): "A expressão 'discurso constituinte' designa fundamentalmente os discursos que se propõem como discursos de Origem, validados por uma cena de enunciação que autoriza a si mesma". Assim, o próprio discurso constituinte pressupõe uma instituição, ao mesmo tempo em que a estrutura.

Considerar o discurso literário como discurso constituinte é tomá-lo como uma categoria discursiva que não deve ser reduzida a unidades linguísticas e nem aos aspectos sociais, históricos ou psicológicos de uma obra. A análise do discurso literário, proposta por Maingueneau, considera os aspectos sociais e históricos enodados aos aspectos de linguagem, sem a comum separação que se faz entre texto e contexto.

A noção de discurso constituinte supõe, conforme Maingueneau (2008, p.43): "[...] certa função (dispor da mais forte autoridade), certo recorte de situações de comunicação de uma sociedade (há lugares, gêneros ligados a tais discursos constituintes) e certo número de invariantes enunciativas." Essas propriedades determinariam as categorias operacionalizadas na análise desse discurso: a cena de enunciação (o tipo de discurso, o gênero discursivo e a cenografia); a dêixis discursiva (enunciador, coenunciador, topografia e cronografia), e a categoria do ethos discursivo. Mais adiante, neste texto, 


\section{Revista do SELL \\ v. $4, n^{\circ} .1$ \\ ISSN: $1983-3873$}

iremos retomar as categorias que serão pertinentes à análise do texto literário de Clarice Lispector. Por ora, consideraremos outra característica dos discursos constituintes, portanto, também do discurso literário, a interdiscursividade.

Para Maingueneau (2008, p.43), os discursos constituintes estabelecem conflitos permanentes entre seus variados posicionamentos, considerando o interdiscurso, isto é, o fato de que "a unidade de análise pertinente não é o discurso em si mesmo, mas o sistema de referência aos outros discursos através dos quais ele se constitui e se mantém". Dessa perspectiva, o que mantém um determinado campo discursivo em funcionamento é a polêmica instaurada nesse campo. Contudo, o autor esclarece que a construção de um posicionamento no campo não diz respeito apenas a determinados conteúdos de uma obra, por exemplo. Maingueneau (2009) propõe que se conceba o posicionamento discursivo, isto é, a constituição de uma identidade discursiva no campo, a partir do modo de funcionamento discursivo resultante das relações inter e intradiscursiva. Essas relações teriam como efeito a inscrição do autor de uma obra no campo discursivo e, portanto, a constituição de seu posicionamento numa comunidade discursiva que compartilha de determinados modos de funcionamento. Entretanto, 0 discurso literário, sendo um discurso constituinte, "não mobiliza apenas autores, mas uma variedade de papeis sociodiscursivos" (MAINGUENEAU, 2008, p.44). Assim sendo, 0 autor de um texto seria entendido como um sujeito social e histórico inscrito em um campo social, inscrição essa que é seu posicionamento nesse campo. Esse posicionamento decorre de um processo histórico definido pelos movimentos de inscrição no interdiscurso, com base nas relações que um autor mantém com outros posicionamentos, outras comunidades discursivas.

Sustentado pela perspectiva enunciativa, segundo a qual o enunciador não é uma exterioridade ao texto e nem uma consciência criadora, Maingueneau (2009) apresenta três categorias que integram, por meio de um atravessamento mútuo e recíproco, a noção de autoria na Análise do Discurso Literário, a saber: a categoria pessoa, que se refere ao indivíduo civil e com uma vida privada; a categoria escritor, que se refere ao ser da instituição literária e que circula por ela; e a categoria de inscritor, que corresponde tanto à subjetividade (aquele que se enuncia) implicada na cena genérica, como aquela implicada pela cenografia do discurso. Essas categorias se articulam constituindo a 'instância criadora' do discurso, em que o jogo de autoria instaurado terá como efeito o autor de um texto, sujeito discursivo construído nesse jogo e que é nomeado a partir de 


\section{Revista do SELL}

v. $4, n^{\circ} .1$

ISSN: $1983-3873$

seus textos escritos e publicados, pela circulação de seu discurso. Vale esclarecer que essa inscrição ocorre por meio do posicionamento do autor na interlíngua.

Considerando que para a Análise do Discurso a materialidade discursiva se constitui da relação entre língua e condições de produção, Maingueneau (2009) afirma que as questões referentes à língua no discurso literário devem se deslocar da língua para a interlíngua, o que significa considerar que:

O escritor não enfrenta a língua, mas uma interação de línguas e usos, aquilo que denominamos interlíngua. Vamos entender por isso as relações que entretêm, numa dada conjuntura, as variedades da mesma língua, mas também entre essa língua e as outras, passadas ou contemporâneas. (MAINGUENEAU: 2009, p.182)

Desse modo, é gerindo seu posicionamento na interlíngua que o autor cria um código linguageiro da obra. Em relação à escritora Clarice Lispector, é seu modo de posicionamento na interlíngua que constitui o que nomeamos de "língua literária estrangeira", por meio da qual a autora tematiza uma característica própria da natureza do discurso literário: sua paratopia.

\subsection{Discursos constituintes são paratópicos}

Como discurso constituinte, o discurso literário autoriza a si mesmo no sentido de se autogerir e se organizar na interlíngua. Entretanto, isso apenas é possível devido ao paradoxo que define todo discurso constituinte: sua condição paratópica. Essa condição decorre do paradoxo de, ao mesmo tempo, pertencer e não pertencer a um campo ou um grupo. De acordo com Maingueneau (2008, p.45):

O discurso literário, por sua vez, inclui numerosos escritores que pretendem operar fora de qualquer pertencimento; mas essa é justamente uma das características da literatura, que seja a de suscitar a pretensão de jogar com a tensão entre a criação solitária e o pertencimento a grupos.

Essa é a condição do pertencimento paradoxal que caracteriza a inscrição do escritor no campo discursivo. O conflito se estabeleceria no fato de que o autor de uma obra não se situa nem fora e nem dentro de uma determinada sociedade; sua localidade seria paradoxal: "não é ausência de qualquer lugar, mas uma difícil negociação entre o lugar e o não lugar, uma localização parasitária, que vive da própria impossibilidade de se 


\section{Revista do SELL}

v. $4, n^{\circ} .1$

ISSN: $1983-3873$

estabilizar" (Idem). Segundo Maingueneau (2008), é esse movimento (de deslocamento) que legitima os discursos constituintes. Diante disso, podemos supor esse movimento de deslocamento impossibilitaria que um discurso se submetesse a determinadas forças sociais ou históricas não colocando, desse modo, em xeque sua autoridade constituinte.

Sobre essa condição de um pertencimento impossível é importante, para compreendermos a tematização paratópica realizada por Clarice Lispector, destacar um aspecto:

[...] só há paratopia se elaborada através de uma atividade de criação e de enunciação [...] a paratopia envolve o processo criador, que também a envolve: criar uma obra é, em um só movimento, produzir uma obra e construir através dela as condições que permitem produzi-la. Não há situação paratópica exterior a um processo de criação: dada e elaborada, estruturante e estruturada, a paratopia é ao mesmo tempo aquilo de que é preciso se libertar pela criação e aquilo que a criação aprofunda, ela é simultaneamente o que dá a possibilidade de alcançar um lugar e o que proíbe qualquer pertencimento. (MAINGUENEAU, 2008, p. 48)

Essa é uma das problematizações de Clarice Lispector na obra Um sopro de vida (Pulsações): o paradoxo da e na criação literária. Como um recorte dentro da obra da autora, Um sopro de Vida nos possibilita compreender a inscrição de autoria de Lispector no campo literário, marcada pelo paradoxo do pertencimento e do não pertencimento a esse campo. Em termos de interdiscurso, o diálogo é com o texto bíblico em que a criação literária dialoga com a criação divina, em que criar personagens - pela e na escrita - é um sopro de vida. Nesse sentido, a problemática da natureza constituinte do discurso literário, nessa obra, estaria tematizada por meio da alegoria da Origem das coisas, da vida, do processo de criação. A autora inscreve-se na posição de um deus criador, não pertencendo, desse modo, à sua criação, mas a um além, no limite entre o sagrado e o humano. Esse percurso de inscrição é constituído na interlíngua, por meio da constituição de uma espécie de 'língua literária estrangeira' de Clarice Lispector, possibilitando, com isso, a transgressão dentro do campo discursivo literário ${ }^{2}$, ou seja, sua inscrição paratópica.

\footnotetext{
2 Vale ressaltar a importante distinção que Maingueneau (2009) faz entre universo, campo e espaço discursivo. Segundo o autor, o discurso tem como especificidade o fato que se estrutura a partir da relação com outros discursos, em uma relação nomeada de interdiscursiva que já abordamos, neste texto. Essa relação se estabeleceria considerando o universo, o campo e o espaço de discursivo, prevalecendo uma concorrência primordial para um discurso entre o campo e o espaço discursivo e que se instaura no campo discursivo. De modo geral, o universo discursivo diz respeito ao conjunto de formações discursivas que interagem em determinada conjuntura e, frente à sua amplitude, não pode ser apreendido em sua
} 


\section{Revista do SELL \\ v. $4, n^{\circ} .1$}

ISSN: $1983-3873$

Ao trazer a criação literária e paratópica como tema nessa obra, na tensão dialógica entre seus dois personagens - um criador e uma criatura - Clarice Lispector tematiza o não lugar dessa criação que constrói um percurso marcado por uma topografia e uma cronografia que a filiam ao campo literário. Porém, as cenografias construídas ao mesmo tempo a deslocam desse campo considerando que sua narrativa é sua cena de enunciação nesse campo discursivo. Com base nessa hipótese é que propomos que essa obra seja pensada em termos de uma metaparatopia: a paratopia discursivizando a paratopia, em que a tensão entre criador e criatura evocaria a tensão paratópica entre a criação literária e o "lugar" dessa criação, no campo discursivo literário.

\subsection{A cena da enunciação: as cenografias paratópicas}

Com base nos fundamentos da análise do discurso literário que elencamos, abordaremos a obra Um sopro de Vida (Pulsações) de Clarice Lispector como uma cena da enunciação epifânica da realização do processo de escrita como um processo difícil e divino de criação. Para a construção dessa cena da enunciação é preciso, seguindo Maingueneau $(2008,2009)$, considerarmos três cenas de um processo enunciativo: a cena englobante, a cena genérica e a cenografia. Conforme o autor, a cena englobante corresponde ao tipo de discurso - literário, político, publicitário, entre outros -, a cena genérica ao gênero de discurso, e a cenografia, no caso do discurso literário e do gênero prosa, concerne a:

[...] uma cena narrativa construída pelo [e no] texto. [...] É nessa cenografia, que é tanto condição como produto da obra, que ao mesmo tempo está 'na obra' e a constitui, que são validados os estatutos do enunciador e do coenunciador, mas também o espaço (topografia) e o tempo (cronografia) a partir dos quais a enunciação se desenvolve. (MAINGUENEAU, 2009, p.252)

totalidade, como por exemplo, o universo científico. O campo discursivo é conjunto de formações discursivas em concorrência, que se delimitam reciprocamente no universo discursivo, como por exemplo, o campo discursivo literário. $O$ espaço discursivo é formado pelos recortes discursivos que o analista isola no interior de um campo discursivo tendo em vista propósitos específicos de análise, como por exemplo, a obra Um sopro de Vida (Pulsações), do conjunto da obra literária de Clarice Lispector. 


\section{Revista do SELL \\ v. $4, n^{\circ} .1$ \\ ISSN: $1983-3873$}

A cenografia legitima e é legitimada pelo discurso e une obra e contexto, funcionando como embreante paratópico: são os modos como o texto gere o contexto que possibilitam ao autor se inscrever no campo discursivo.

$\mathrm{Na}$ análise da obra de Clarice Lispector, consideraremos quatro cenografias construídas em torno de seus dois personagens: o Autor/Narrador e Angela Pralini, Personagem/Autora. Nessas cenografias, o funcionamento se caracteriza, de antemão, pela possibilidade de uma inscrição alternada desses personagens na posição de enunciador, em uma alternância comum aos discursos paratópicos: uma alternância de inscrição, de posicionamento no campo discursivo no tenso jogo entre a criação literária e o lugar dessa criação na voz de Ângela Pralini requerendo seu lugar, sua autonomia, independente de seu "Autor". Por sua vez, este também se questiona sobre o seu lugar em relação ao que está criando e seu controle sobre isso, sobre sua criação. Em relação à cronografia construída nas cenografias, nossa hipótese é que ela se caracteriza como o momento, o tempo do percurso da criação, da narrativa, e a topografia, como o lugar da criação construído no interdiscurso e na interlíngua.

Considerando essa dêixis discursiva (topografia, cronografia, enunciador e coenunciador), iremos analisar a obra Um sopro de Vida (Pulsações), buscando reconstituir a cena de enunciação por meio da qual é possível dizer sobre a inscrição paratópica de Lispector no campo literário.

\section{Um sopro de Vida (Pulsações): a cena da enunciação}

Para a análise do discurso, apresentaremos as quatro partes que compõem a narrativa de Um sopro de Vida (Pulsações). São elas: uma primeira parte com função de um prólogo inicial, uma segunda parte intitulada $O$ sonho acordado é que é a realidade, a terceira parte Como tornar tudo um sonho acordado? e uma última parte, o desfecho da obra que, sem título e de modo intenso, encerra essa obra desencadeando uma continuidade no processo de criação: há um efeito para além do fim de um livro quando o que está em jogo é a criação do texto literário.

De modo geral, no nível enunciativo, há uma alternância entre a primeira pessoa e terceira pessoa do singular e um corte na ordem do espaço e do tempo da narrativa, em que questões como onde e quando não podem ser respondidas de modo direto, construindo outro foco narrativo. 


\section{Revista do SELL \\ v. $4, n^{\circ} .1$ \\ ISSN: $1983-3873$}

Sant'anna (1973), fazendo uma análise do conjunto da obra de Clarice Lispector, aponta para a exaustiva presença do que nomeia de referenciadores da epifania, isto é, palavras que remetem, nas obras, à epifania como tema e recurso estilístico da escritora. Por analogia, propomos, para a análise das cenografias, a expressão referenciadores da paratopia para os termos (embreantes) que ligam o enunciado à sua condição paratópica. Esses referenciadores de paratopia dizem respeito às palavras que trazem um antagonismo semântico e que aparecem ao longo da obra nas cenografias paratópicas, fazendo referência à condição de autoria nessa obra.

Em Um sopro de vida (Pulsações), podemos, como leitores, acompanhar a escrita de um livro desde um momento inicial da tensa decisão de escrever esse livro, passando pela criação do personagem, por sobre o que escrever, pelo confronto entre o criador e a criatura, até o momento epifânico, cujo efeito é o desfecho final da obra, em que o Autor da obra que está sendo escrita em Um sopro de Vida (Pulsações) sucumbe a essa obra, colocando em cena a morte literal desse Autor.

O livro Um sopro de Vida (Pulsações) foi construído em significativa relação com outros discursos e evocar esses discursos, antes da análise das cenografias consideradas paratópicas, se justifica pelo fato deles, ao longo de toda a obra, emergirem do interdiscurso, funcionando como uma espécie de cenário para o movimentar-se paratópico na obra. Referimo-nos ao discurso religioso naquilo que o define como constituinte, e ao discurso artístico, mais especificamente ao discurso da música, com os quais o discurso literário nesse livro estabelece relações de tensão e polêmica.

Consideremos o trecho a seguir, em que é possível identificar a relação instaurada, na obra em questão, com o discurso religioso.

(1) "AUTOR. - - Foi Deus que me inventou e em mim soprou e eu virei um ser vivente. [...]" (p.28)

Nesse recorte, o tempo discursivo é o passado, marcado nos verbos de ação inventar e soprar, validando, na obra, o estabelecimento de uma polêmica com o discurso religioso. O situar-se no limite paradoxal que marca o campo do discurso literário é validado, em toda a obra, na cena do discurso religioso, como podemos ver na indicação paratextual da epígrafe no início da obra: "Do pó da terra formou Deus-Jeovah o homem e soprou-Ihe nas narinas o fôlego da vida. E o homem tornou-se um ser vivente." (Gênesis, 2,7). Ao construir as cenografias de Um sopro de Vida (Pulsações) na relação com o 


\section{Revista do SELL \\ v. $4, n^{\circ} .1$ \\ ISSN: $1983-3873$}

discurso religioso, mais especificamente por meio da cena validada da criação divina, instaura-se, ao longo de dessa obra, uma relação com o sagrado, o que acaba por legitimar um certo tom de sacralidade ao literário. Essa qualidade de sagrado não se relaciona com santidade tal qual se privilegia no discurso religioso. No discurso literário trata-se, em seu sentido grego, de um poder: do poder subversivo da escrita literária.

O trecho abaixo, por sua vez, marca a presença do discurso da música na obra analisada.

(2) "AUTOR. - "Estou ouvindo música. Debussy usa as espumas do mar morrendo na areia, refluindo e fluindo. Bach é matemático. Mozart é o divino impessoal. Chopin conta a sua vida mais íntima. Schoenberg, através de seu eu, atinge o clássico eu de todo o mundo. Beethoven é a emulsão humana em tempestade procurando o divino e só o alcançando na morte. Quanto a mim, que não peço música, só chego ao limiar da palavra nova. Sem coragem de expô-la. Meu vocabulário e às vezes wagneriano-polifônico-paranóico. Escrevo muito simples e muito nu. Por isso fere. Sou uma paisagem cinzenta e azul. Elevo-me na fonte seca e na luz fria." (p.15-16)

Construir a cenografia da obra tendo como trilha sonora a "grande música" é, mais uma vez, constituir uma topografia e uma cronografia que se apresentam para além, acima do lugar comum, do ordinário da vida alçando esse discurso literário a certa sacralidade, uma vez que é sublime e quase intocável justamente por seu pertencimento paradoxal, por estar acima do lugar comum, desse ordinário da vida.

\subsection{O prólogo: "Quero escrever movimento puro"}

A cenografia introdutória de Um sopro de Vida (Pulsações) foi escrita depois do livro pronto, conforme relata o ainda somente sujeito-narrador, cuja função é assumir a responsabilidade pela obra (marcada pelo uso da primeira pessoa) e colocar o leitor como um interlocutor ignorado na difícil negociação entre estar convocado ou não a estar inscrito no campo literário e interrogando-se como responder a isso, uma vez que há uma ruptura da narrativa romanesca com o romance tradicional. A obra, como cena genérica, constitui-se de dois diários, um do sujeito Autor/Narrador e outro do sujeito 


\section{Revista do SELL \\ v. $4, n^{\circ} .1$}

ISSN: $1983-3873$

Personagem/Autora Ângela Pralini ${ }^{3}$. A cenografia do diário impõe, no caso do romance em questão, o paradoxo de ser escrito para não ser lido por outros leitores que não o próprio sujeito enunciador. Nessa perspectiva, o outro do sujeito enunciador é a própria criação, seu próprio texto. Este índice constrói a paratopia de Clarice Lispector, no sentido de que, ao menos em termos de cenografia, isto é, de cena construída no/pelo texto, o efetivo leitor da obra não ser necessário. O grande tema é a criação, e o interlocutor é o próprio criador.

(3) "[...] Eu escrevo para nada e para ninguém. Se alguém me ler será por conta própria e autorrisco. Eu não faço literatura: eu apenas vivo ao correr do tempo. $O$ resultado fatal de eu viver é o ato de escrever. Há tantos anos me perdi de vista que hesito em procurar me encontrar. Estou com medo de começar. Existir me dá às vezes tal taquicardia. Eu tenho tanto medo de ser eu. Sou tão perigoso. Me deram um nome e me alienaram de mim." (p.16)

Instaura-se, nesse momento inicial, um acontecimento e uma cena, e como nos prólogos do antigo teatro grego, uma tragicidade: "Isto não é um lamento, é um grito de ave de rapina. Irisada e intranquila. O beijo no rosto do morto." (p. 13). A morte, como desfecho desse drama da escrita a ser escrito, é anunciada: somos avisados que a batalha entre sujeito Autor e sujeito Personagem, entre autoria e obra, terminará na morte de um: quem permanecerá vivo no campo literário? O sujeito Autor criador, ou sua personagem criatura, metáfora da obra literária? Nessa abertura, apresenta-se o grito de ave de rapina demarcando um lugar de domínio, mesmo que ainda irisada e intranquila.

$\mathrm{Na}$ cenografia introdutória da obra, é também onde o sujeito Narrador/Escritor ("Eu escrevo") indica o tempo e o espaço do que virá: "Do zero ao infinito vou caminhando sem parar.” (p.13). Não se saberá, ao longo da obra (e nenhuma cenografia mostrará isso), onde e quando vivem os personagens: hora é de dia, hora de noite, hora se está na cidade, hora a natureza é o espaço.

Decidido a escrever um livro e a assumir-se, portanto, enquanto Autor, o sujeitonarrador se apresenta, entretanto, em conflito com essa inscrição e relutante em escrever,

\footnotetext{
${ }^{3}$ A personagem Ângela Pralini aparece pela primeira vez no conto "A partida do trem", publicado em Onde estivestes de noite, de 1974, encarnando a juventude diante da personagem Dona Maria Rita Alvarenga Chagas Souza Melo. Trata-se do que, posteriormente, neste texto, chamaremos de um referencial paratópico: a personagem central de Um sopro de Vida encarna a paratopia, um outro lugar: ela vem de outro lugar para existir, também, em outro lugar discursivo.
} 


\section{Revista do SELL}

v. $4, n^{\circ} .1$

ISSN: $1983-3873$

apesar de assumir essa autoria: "Eu escrevo". De início, o enunciador não instaura um pacto com o leitor, deixando a ele a escolha por ler ou não o que está escrito, evocando o não controle que um autor tem de sua obra quando esta é colocada em circulação. Ainda, tematiza a instabilidade do lugar de quem escreve e do limite perigoso que há entre ser um autor, um nome e ser ele mesmo. Assim, o lugar construído, nessa cenografia, está suspenso entre um nome que responde por essa obra que se escreve e o ser, a subjetividade aí implicada. O Autor teme o assujeitamento de sua condição de autoria e a teme por saber que, histórica e institucionalmente, não é possível escapar dessa alienação a um nome de autor, o que poderia evocar um assujeitamento também em relação a um estilo e à sua eterna repetição, retirando da criação literária sua indefinição constitutiva. Diante disso, coloca-se em cena a conflituosa figura da autoria: teme-se escrever uma obra e ser reduzido a ela, sendo reconhecido apenas por meio dela.

\subsection{O sonho acordado é que é a realidade: o diário do autor}

Ao escrever seu diário (uma fotografia que registra o momento de criação, que captura esse instante), o sujeito-narrador assume-se Autor e, nele, irá narrar seu movimento de escrever e seu confronto com sua criação, a sua Personagem/Autora Ângela Pralini. Decido a escrever seu livro, esse sujeito Autor apresenta-se, nessa cenografia epifânica ("O sonho acordado é que é realidade"), como o enunciador dessa obra que falará consigo mesmo durante todo o tempo da escrita. Essa epifania evoca uma cronografia e uma topografia marcadas pelo instante de transformação: um não lugar e um momento instantâneo, como uma fotografia. Esse instante existencial é a realidade não inscrita em lugares e em tempos reais, mas inscrita em outro lugar, como uma manifestação mística. Essa cenografia emerge da relação com discurso religioso, uma vez que o instante de transformação existencial e profundo é uma revelação, uma manifestação divina. Essa epifania marca o fora, o não pertencimento a um lugar, mas a outro lugar, porém não nomeável.

Na sequência, em (4), o sujeito Autor evoca a condição marginal dos escritores, dos autores de literatura: os autores românticos do século XIX, os poetas das tavernas e da boemia, indiciando qual é o lugar propício para a criação literária, pois ser Autor é ser marginalizado, é estar à margem dos grupos instituídos. Todavia, esse lugar feito de atalhos também permite a aceitação, a entrada em espaços sociais reconhecidamente 


\section{Revista do SELL \\ v. $4, n^{\circ} .1$ \\ ISSN: $1983-3873$}

aceitos como o lugar daquele que é bem-sucedido, é reconhecido pelos seus pares, é aceito institucionalmente e pelo público:

(4) "AUTOR. - [...] Só que eu sou marginalizado apesar de ter mulher e filhos marginalizado porque escrevo. Pois em vez de seguir pela estrada já aberta enveredei por um atalho. Os atalhos são perigosos. Enquanto Ângela é enquadrada e social." (p.32)

Ainda, nessa sequência, podemos demarcar a tensão constante entre o sujeito Autor e Ângela Pralini. É o jogo contraditório do pertencimento, da inscrição de autoria no campo discursivo da literatura que está descrito e narrado nos nomes das personagens de Um sopro de Vida (Pulsações). Como podemos ver em (4) e, também, ao longo de toda essa obra, Clarice Lispector não nomeia seu personagem-autor, ele é simplesmente o Autor, sua nomeação subjetiva é ser autor, responder por uma obra. Porém, Clarice Lispector, por meio de seu Autor/Narrador, nomeia a personagem autora Ângela Pralini, que é reconhecida como autora, que é enquadrada socialmente, enquanto o Autor é sem nome, sem lugar. É o quadro pintado, por Clarice Lispector, que poderia ser chamado de 'Paratopia', e seu autor pintado é "um mendigo de barba cheia de piolhos sentado na calçada da rua chorando" (p.89).

Passemos, agora, às variadas marcas textuais que compõem essa cenografia paratópica e que, anteriormente, nomeamos como referenciadores paratópicos, referenciadores da paratopia. Os termos validados como referenciadores paratópicos compõem um jogo semântico caracterizado pela contradição entre si e por serem usados em referência ao que é escrever, ser Autor. São eles: legível, escuro nítido, inexplicável, incógnito, marginalizado, enquadrada, social, gelado, atordoante, imitadores, popularidade, escuridão, além-escritura, além-vida, além-palavra, erudição, imprecisão, suicida, dualidade, liberdade, equilibrar-se, instável, mulherice, claro, escuro, enredado, impossível, perdido, individualidade, sucesso, desocupado, semianalfabetos, paradoxal, vazio, plenitude, escritor, personagem, desapego, alegre, triste, isento, incólume, gratuito, enredado, perdido, contrário, estrangeiro. Considerando o uso da palavra feito por Clarice Lispector, que a considera coisa usada para pintar, fazer paisagens, essas marcas lexicais evocam a paratopia encarnada no verbo, no jogo entre o possível e o impossível, entre o pertencimento e não pertencimento: o lugar, do zero ao infinito, da inscrição de 


\section{Revista do SELL}

v. $4, n^{\circ} .1$

ISSN: $1983-3873$

autoria. Para além das palavras, essas marcas gerem o texto e o contexto em termos discursivos construindo o campo discursivo literário e nos dizendo como se caracteriza esse campo: são os adjetivos caros à autora de Um Sopro de Vida (Pulsações) e que marcam essa posição de autoria como um processo paratópico e conflituoso, pois são escolhas lexicais de campos semânticos diversos.

\subsection{Como tornar tudo um sonho acordado?: o diário de Ângela Pralini}

Na cenografia construída tendo como enunciador Ângela Pralini, essa autora que tem um nome e um lugar social, mantém-se a cronografia e a topografia da cenografia anterior. Contudo, a tentativa de Ângela é escrever seu livro-diário mais próximo da cena genérica romanesca tradicional: pequenas histórias de coisas que a cercam: A casa, $\mathrm{O}$ relógio, O gradil de ferro, O carro, A Vitrola, Borboleta, entre outras. Ainda, essa personagem Ângela Pralini se apresenta e é apresentada pelo seu Autor como tapeceira, pintora, escultora, compositora, rendeira, antes de se definir por ser escritora, de assumirse escritora, chegando a se confundir com seu próprio Autor e, ao tomar para si a autoria de Cidade Sitiada, assume a posição discursiva da autora Clarice Lispector trazendo essa autora para dentro do texto e, em termos discursivos, essa referência a outra obra, tem um funcionamento do que definimos de referencial paratópico. O Autor, na dificuldade de definir para si uma identidade, delega a Ângela Pralini, sua personagem, a função de autoria: de escrever seu livro, criar sua obra.

(5) "ÂNGELA. - Gosto de palavras. Às vezes me ocorre uma frase solta e faruscante, sem nada haver com o resto de mim. Vou de agora em diante escrever neste diário, em dias em que não haja mais o que fazer, as frases quase à beira de não ter sentido mas que soam como palavras amorosas.

Dizer palavras sem sentido é minha grande liberdade. Pouco me importa ser entendida, quero o impacto das sílabas ofuscantes, quero o nocivo de uma palavra má. Na palavra está tudo. Quem me dera, porém, que eu não tivesse esse desejo errado de escrever. Sinto que sou impulsionada. Por quem?

Eu quero escrever com palavras tão agarradas umas nas outras que não haja intervalos entre elas e entre eu.

Eu quero escrever bem zangada. Quanto a mim, eu sou de longe. Muito longe. E de mim vem o puro cheiro de querosene." (p.95) 


\section{Revista do SELL}

v. $4, n^{\circ} .1$

ISSN: $1983-3873$

O sujeito-autor Ângela Pralini, antes apresentada como enquadrada socialmente pelo seu Autor, ao assumir a função de autora de uma obra começa a dar indícios de um não pertencimento, como é possível perceber em (5): já não se importa em ser entendida, assume o perigo de escrever e se situa longe (topografia da cena), muito longe. Como enunciadora legítima dessa cenografia ("Eu quero" - primeira pessoa), ela se inscreve, como autora, no campo discursivo da literatura. Porém, sofre, de modo imediato, no instante da escrita (cronografia da cena) o efeito desse posicionamento: passa ao lugar do limite, do conflito em ser marginalizada. Nesse sentido, esse movimento de Ângela Pralini caracteriza essa cenografia como uma construção paratópica: ao dizer da paratopia, a coloca como constitutiva da autoria e, ao se inscrever como autora, sofre os efeitos dessa condição.

(6) "AUTOR.- Me coisificam quando me chamam de escritor. Nunca fui e nunca serei. Recuso-me a ter papel de escriba no mundo. Eu odeio quando me mandam escrever ou quando esperam que eu escreva. Recebi uma vez uma carta anônima que me oferecia espiritualmente um recital de música contanto que eu continuasse a escrever. Resultado: parei completamente. Só quem manda em mim - eu é que sei." (p.97)

Ao ser evocado na cenografia construída por Ângela Pralini, o Autor só vem ratificar sua condição paratópica, como vemos em (6). Porém, é possível perceber uma revolta diante dessa condição, uma reação a essa condição: revolta na própria palavra, no movimento de escrever, quando diz que nunca foi e nunca será escritor. Mas o que se tem aí é um conflito entre os que mandam escrever e os que escrevem quando querem. Esse Autor revoltado e indignado instaura-se no espaço desse conflito, nesse limite entre o que devemos fazer diante de nossas inscrições sociais e históricas e o que queremos fazer. Esse conflito não cessa; diferentemente, faz caminhar a criação literária.

Encarnando a paratopia na palavra, os referenciadores paratópicos colocados nessa cenografia são: fora d'água, preguiçosa, esvoaçante, encrencado, crônicas, paraliteratura, pseudoescritora, largo, livre, deserto, estado-coisa, doida, misteriosa, livre, fraca, dúbia, charlatã, verdade, vice-versa, inconcludente, contraditória, banalidade, agonizando, esfingética, risco de vida, semimergulhada, dualidade, ceu-ar, terra-mar, tonta, infeliz. Nessa cenografia, tratam-se de escolhas lexicais que não somente 


\section{Revista do SELL \\ v. $4, n^{\circ} .1$ \\ ISSN: $1983-3873$}

caracterizam o processo de autoria, mas que também nomeiam o que é criado nesse processo, o que nasce de um sopro de vida.

\section{4 Última parte: o desfecho}

Após o clímax epifânico, validado como funcionamento da obra, segue-se seu desfecho e, nesse momento final, a cenografia construída evoca a paratopia como condição da autoria na imagem do Autor andarilho que, andando a esmo, sacia sua sede e se funde com a imagem do próprio Deus criador que reposou após terminar sua obra. Mas, um autor na figura da pessoa não é imortal: autores morrem antes de suas obras, se é que elas morrem algum dia. Ângela, criação do Autor sobrevive a ele e, tendo o amanhecer como topografia dessa última cenografia, uma nova obra será iniciada, será escrita. É a morte do Autor, metáfora da condição paratópica da autoria, que presenciamos ao ler o desfecho de Um sopro de Vida (Pulsações), em contraponto à continuidade de Ângela, metáfora da continuidade de uma obra literária como discurso.

(7) “AUTOR. - Ângela é mais forte do que eu. Eu morro antes dela. Era um dia um homem que andou, andou e andou e parou e bebeu água gelada de uma fonte. Então sentou-se numa pedra e repousou o seu cajado. Esse homem era eu. E Deus estava em paz.

ÂNGELA.- Está amanhecendo: ouço os galos. Eu estou amanhecendo." (p.159)

Nessa cena, temos o desenlace desse drama de criação do texto literário. Porém, não se trata de um fim, mas de um efeito e de uma continuidade instaurada nesse processo de autoria, o efeito do discurso literário para além de seu campo. Ângela continuará... O processo de criação não cessa como processo de autoria.

\section{Considerações finais}

Tratamos, neste texto, da inscrição de autoria da escritora Clarice Lispector, no campo discursivo literário brasileiro, com base nas cenografias construídas na e pela obra Um Sopro de Vida (Pulsações, 1999).

Por meio das análises das quatros cenografias que compõem essa obra, foi possível verificar que essa inscrição se caracteriza por uma condição paratópica coerente 


\section{Revista do SELL \\ v. $4, n^{\circ} .1$ \\ ISSN: $1983-3873$}

com a natureza do discurso literário. Também foi possível verificar que a obra tematiza essa paratopia por meio de um funcionamento que propusemos nomear de metaparatópico, uma vez que as cenografias dizem sobre a paratopia, ao mesmo tempo em que são paratópicas. Diante disso, a inscrição de autoria de Clarice Lispector se caracteriza por ser paratópica e por fazer dessa condição o funcionamento dessa obra. Entretanto, não nos parece, após esse percurso, que a escritora sucumbe a essa condição. Ao contrário, ao fazer dela um de seus temas e trazê-la ao enfrentamento personificado pelos seus personagens, Clarice Lispector cumpre sua função de autora: dizer sobre os paradoxos humanos, e a paratopia dos discursos constituintes é efeito e causa desses conflitos, se pensarmos na relação que temos com discursos como o discurso literário e o discurso religioso. Essa relação é a mesma enfrentada pela escritora Clarice Lispector: paratópica.

Assim sendo, a tematização de Clarice Lispector acerca da paratopia nos ajuda a compreender a autoria, em análise do discurso, como uma inscrição paradoxalmente necessária no campo discursivo literário. Ao considerarmos a autoria como um posicionamento, a inscrição social e histórica de um escritor no campo discursivo literário, é preciso levar em conta que essa inscrição ocorre no limite desse campo, na relação com os mais variados espaços e campos discursivos e, se a obra literária é efeito dessa inscrição, ela trará as marcas do paradoxal, seja pelas vias de fato, como em Um sopro de Vida (Pulsações), ou pelas infinitas possibilidades que a língua (a interlíngua) oferece por meio de seus recursos estilísticos, discursivos, textuais.

Para finalizar, é importante ressaltar que não falamos de um dentro ou fora do texto, da obra, mas de um contexto gerenciado por um texto, cujas cenografias funcionariam como embreantes paratópicos, como na obra analisada: apesar de sua inscrição e tematização paratópica, a obra de Clarice de Lispector não está isolada do contexto no qual se constituiu; diferentemente, a escritora negocia no/com o campo discursivo, negociando incessantemente sua condição paratópica de autoria.

\section{Referências Bibliográficas}

CÂNDIDO, A. No raiar de Clarice Lispector. In: Vários escritos. São Paulo: Duas Cidades, 1977, p. 125-131.

LISPECTOR, C. Um sopro de vida (Pulsações). Rio de janeiro: Rocco, 1999. . Perto do Coração Selvagem (1944). Rio de Janeiro: Rocco, 1998. 


\section{Revista do SELL}

v. $4, n^{\circ} .1$

ISSN: $1983-3873$

MAINGUENEAU, D. Os discursos constituintes. Trad. Nelson Barros da Costa. In: - Cenas da enunciação. POSSENTI, S. \& SOUZA-E-SILVA, M.C.P. de (Orgs.). São Paulo: Parábola, 2008, p. 37-54. Discurso Literário. Trad. Adail Sobral. São Paulo: Contexto, 2009.

MOSER, B. Clarice, uma biografia. Trad. José Geraldo Porto. São Paulo: Cosac Naify, 2009.

MUSSALIM, F. Análise do discurso literário: campo discursivo e posicionamento na interlíngua. Curitiba: Anais do VII Congresso Internacional da Abralin, 2011(a). p. 1451 1465. 